\title{
Market structure and Islamic banking performance in Indonesia: An error correction model
}

\author{
Alfi Maghfuriyaha*, S. M. Ferdous Azam ${ }^{a}$ and Sakinah Shukria
}

${ }^{a}$ Post Graduate Centre, Management and Science University, University Drive, Off Persiaran Olahraga, Section 13, 40100, Selangor, Malaysia

\begin{tabular}{l}
\hline C H R O N I C L E \\
\hline Article history: \\
Received: April 15, 2019 \\
Received in revised format: April \\
272019 \\
Accepted: May 11, 2019 \\
Available online: \\
May 11, 2019 \\
\hline Keywords: \\
Structure Conduct Performance \\
Market Structure \\
Islamic Banking \\
Performance
\end{tabular}

A B S T R A C T

The research aims to highlight the importance of market structure and behavior on Islamic banking performance by using the Structure Conduct Performance (SCP) analysis to approximate the growth of Islamic banking performance in the short and long term using error correction model. The data used in this study is time series obtained from the financial statement of each Islamic bank, Financial Service Authority and Bank of Indonesia on Islamic banking statistics monthly reported from April, 2015 to October, 2018. Population of this study covers all Islamic commercial banks in Indonesia. The purposive sampling method is used to select samples based on criteria to get samples that are feasible to be analyzed. Error correction model is applied to characterize the joint dynamic of variables in both in the long and short term relationships. The Johansen co-integration results indicate a stable long term relation between market structure and Islamic banking performance. Results show that Market structure variable outside market share of financing in the long term had a significant effect on the Islamic banking performance, but in the short term market structure, the variable had no significant effect on the Islamic banking performance in Indonesia.

\section{Introduction}

Islamic finance has the potential to improve the level of country's interrelated intermediary activities by offering numerous impartial solutions compared with conventional corporate practices (Abidin \& Haseeb, 2018). The Islamic banking as the part of Islamic finance system is considered to be a developed segment of the global financial market with a broad perspective; it is proliferating in all parts of the globe (Nizar, 2015). Islamic Banks established themselves in the comparatively short period by capturing a good market share from its competitors (Basheer et al., 2018). Investigation on the effect of market structure and Islamic banking performance is performed based on the Structure Conduct Performance (SCP) analysis. The market power of the bank will affect the behavior and then affect the performance, so there is a paradigm to analyze the significant effect of the linkage between the market structure, conduct and performance; namely Structure Conduct Performance (SCP) analysis. Market structure is the industry characteristic that affects the price/output decision made by the firms. The SCP framework examines the degree of concentration in a specific market which influence on the competition among companies in that market (Naylah, 2010; Katib, 2004; Bhatti \&

* Corresponding author. Tel.: +601115444915

E-mail address: maghfuriyahalfi@gmail.com (A. Maghfuriyah) 
Hussain, 2010). The high concentration of the market will affect competitive domination. The effects are that firms in less competitive condition will charge higher prices and earn the monopolistic income.

The Islamic banking and financial services industry have shown rapid growth during the last ten years, having accomplished a milestone reaching a value of more than \$2 trillion by 2015 (Haseeb, 2018). Along with improving national economic performance, the grow of the Islamic banking industry in 2017 records good encouraging growth from the asset, financing, and third-party funds (TPF). Islamic banking growth which consists of Islamic Commercial Banks (BUS), Islamic Business Unit (UUS) and Islamic Rural Bank (BPRS), although experienced little slowdown compared with 2016, asset, financing, and Third Party Fund (TPF) growth are still maintained a quite high number (two digits), that is, each amounting to $18.97 \%, 15.24 \%$ and $19.83 \%$ (Islamic Financial Report, 2017). The high growth of Islamic banking assets is mainly underpinned by the growth of investment and financing managed by Islamic banks. This shows that public trust is maintained to save funds in Islamic banks and people who want to get financing from Islamic banks. Likewise, the development of Islamic banking growth is supported by capital, sufficient liquidity, financing quality, and efficiency of Islamic banks.

The total asset of the Islamic banking industry in Indonesia during 2015 - 2018(Q3) increased 43.43\% in the last four years so with the number of Islamic banking which increased from 12 to 13 Islamic banks. In 2015, the assets of Islamic banking was 213.423 billion increased to 306.121 billion in 20189(Q3). The growth of the market share of Islamic banks in Indonesia was more than $0.25 \%$ in 2001 to $3.98 \%$ in 2011, rose to $4.86 \%$ in the year 2015 and $5.74 \%$ in 2017 lagging behind the expected target to achieve $15 \%$ (Islamic banking Statistic, 2017). The Islamic banking industry was able to show a high growth accelerated to an average of $19.92 \%$ year by year during the last five years (2011-2015), while the average growth of the national banking system amounted to only $13.9 \%$ year by year. Islamic banking in Indonesia still has a long way to achieve the target market of Islamic banking based on the blueprint of Islamic banking. The market concentration of the Islamic bank in Indonesia also has a high level of concentration. The market power is managed by some of the Islamic bank both in an asset, third party fund, and financing. The bank which has the most significant market share and the biggest income can earn the supernormal profit. The regulation from the government, Bank Indonesia, and Financial Service Authority (FSA) as an effort to increase the performance of each bank are still in progress.

This study is to investigate the relationship between market structure and Islamic banking performance in Indonesia for the long term and short term relationship use structure conduct performance analysis. The market structure variables used in this study are concentration ratio, Herfindahl-Hiershman Index, and market share. The SCP analysis has been applied in different industries in terms of economic factors. In the banking sector, this paradigm is used to determine the effect of the possible linkage between market structure and profits. While several studies have supported this hypothesis, some others have found that greater concentration does not lead to higher profits (Ahamed, 2012; Arize et al., 2008). Therefore, it is necessary to do more research about the structure of performance which is according to the literature and previous studies, market structure and behavior of the banks have to influence the performance of banks.

This issue is one of the essential topics, not only for the parties of Islamic banking but also the regulator such Bank Indonesia, Financial Service Authority, and Government to make some breakthrough in developing Islamic Banking in Indonesia and to take a right decision in developing Islamic banking performance growth. Globally, the result of this research will describe the specific relationship between market structure, behavior, and performance of Islamic banking in Indonesia in the short term and long term relationship. Learning more about the linkage between market structure and Islamic banking performance will be useful for organizations and regulators, specifically, to distinguish the basic determinants of the performance of the Islamic Banks. This paper analyzes the impact of market concentration and different components of market structures on the performance of Islamic banking in Indonesia in the long and short run relationship. 


\section{Material}

This section will explain the literature review consist of structure conduct performance, market structure, market concentration, market share, and performance of Islamic banking. This research uses structure conduct and performance (SCP) approach to analyze the significant effect of market structure and Islamic banking performance in Indonesia.

\subsection{Structure Conduct Performance}

Structure Conduct Performance (SCP) is a theory which states that the market structure occurs because of the policies (by design) that are applied to a particular sector or industry (Beck et al., 2003, 2006). Policies that restrict the level of competition in the industry such as mergers and acquisitions policy or policies related to market entry barriers (barriers to entry) can form a concentrated market structure. This strong market subsequently forms of collusion between actors in it, which in the end only formed a few players who will enjoy supernormal profits. Collusion among market participants enables the bank to set a price higher than the current price compared with; when the market is at a high level of competition. The implications of the market, in the end, is inefficiency. The market structure occurs because of the policies (by design) that are applied to a particular sector or industry (Beck et al., 2003, 2006). Policies that restrict the level of competition in the industry such as mergers and acquisitions policy or policies related to market entry barriers can form a concentrated market structure (Beck et al., 2003, 2006). This strong market subsequently forms of collusion between actors in it, which in the end only formed a few players who will enjoy supernormal profits (Beck et al., 2003, 2006; Nurwati, et al.; 2014; Belkhaoui et al., 2014). The implications of the market, in the end, is inefficiency (Beck et al., 2003, 2006).

\subsection{Market Structure}

The main factor in bank performance is market structure. The structure is one of the important variables that will affect the behavior in an industry because it explains about the market segmentation going on in the industry, diversification of existing product, the structure of the costs incurred in the market, as well as it explains various obstacles that happen to fall within a competition. At the end, the structure will affect the quality of the performance within the company. As indicated by Koch in Naylah (2010), the structure of the market is the generally permanent strategic component of the nature of a firm that impact, and are affected by the conduct and the performance of the firm in the market roommates it operates.

\subsection{Market Concentration}

Shepherd in Naylah (2010) states the concentration level as a combination of market share from the market leader companies, where the amount should not be less than 2 (two) and more than 8 (eight). The concentration ratio is the percentage of the value of sales represented by some largest firms in the industry (Bade \& Parkin, 2007). Industries that have a high level of concentration tend to have poor performance. This is because the companies that are in the industry cannot allocate its resources efficiently, while the industry with a low concentration level is more likely to be able to allocate its resources efficiently to create a better performance. The most common size in the measurement of the concentration ratio of the market has been the widely used to measure the market share of the output, turnover, number of employees or the total value of the assets of the industry. Concentration Ratio (CR) is defined as the percentage of the overall industrial output generated by the largest companies. Usually, the number of companies that count is 4, so often referred to as $\mathrm{CR}_{4}$ (Douglas in Maghfuriyah, 2017). Usually, the number of companies that count is 4, so often referred to as CR4 (Douglas, 1992). Bade and Parkin (2007) stated that Herfindahl-Hirschman Index (HHI) is the square of the percentage market share of each firm summed over the largest 50 firms (or summed over all the firm if there are fewer than 50). Herfindahl- 
Hirschman Index (HHI) is used to obtain an accurate description and mutual support of the analysis concentration ratio (CR). HHI focuses on a certain proportion of the market share in the industry.

\subsection{Market Share}

Market share is the section market dominated by a company as the strength of the market or better efficiency for achieving better economies of scale. The market has become central in assessing market power. Small market share indicates that companies are not able to face the competition (Katib, 2004). The market share of each company is in different ranges from 0 to $100 \%$ of the total output of the entire market. According to the Neo-Classical literature, the market share achieved is the foundation of enterprise bargaining. Motivation or purpose of the company is to gain a large market share in the industry. Companies with a large market share will gain from the sale of products and the increase in its share price (Naylah, 2010). According to Schuster (1984) a company with a larger market share of more profitable for large economic scale have greater market power and better manage quality. The role of market shares as well as elements of the market structure is a source of profits for the company as a general hypothesis that the market share of each company is associated with gains (Arize et al., 2008).

\subsection{Performance}

Performance is the result of market behavior. Performance is multidimensional and has linkage to the fundamental of interest (Rahman et al., 2018). This performance illustrates how the market condition in an industry organization is, discusses the market performance of efficiency, justice and progress. Efficiency describes how well the market is in utilizing the limited resources. Justice explains how unfair the market in distributing the benefits of economic activity to the economic actors, while market effectiveness can explain changes in new and better products and progress in production techniques (Naylah, 2010). According to Molyneux and Forbes in Katib (2004), the banking industry is a multi-product industry; the use of the price can be misleading because of the cross-subsidies between the goods and services offered. Company performance is measured by financial success and profitability such as return on assets (ROA), return on equity (ROE), return on sales (ROS), and return on investment (ROI) (Rahman et al., 2018). The banking performance in this study is measured by return on asset (ROA) ratio that can be seen in the Islamic banking statistic. Market power has settled the company to maximize the profit by pricing level that formed monopoly structure. But the effective market structure is the market with perfect competition where only the price and quality talk. The competition is created by differences in the performance of every company in the industry. The efficiency of production and allocation (function of the productivity of assets and the costs) can measure the company's performance (Basheer et al., 2018). The efficiency of production and allocation can measure the company's performance. Market structure and profit are benchmark in production efficiency while market force is a benchmark in the allocation of efficiency. Allocation efficiency and fairness will create resemble the behavior of perfect competition. Meanwhile, the productive efficiency would create a market with few companies with different products.

\section{Methods}

This section explains about data and methodological framework to conduct the research. The methodological framework contains the data analysis technique for testing the data in the error correction model.

\subsection{Data Source}

This study utilized monthly time series data for the period 2015M4 to 2018M9. The datasets were acquired from the Islamic banking monthly report and Islamic banking statistics published by the Financial Service Authority and the financial statement of each Islamic bank in Indonesia. While the source of the data used in this research is secondary data, the research data were obtained either indirectly or through 
an intermediary medium. In particular, the total merchandise of monthly market structure and performance data (measured in Indonesia rupiah value) was used for the study. The variables of the study are in ratio from before the estimation process.

\subsection{Method}

The methodology is described as the time series data and the econometric techniques utilized in the study. The Augmented Dickey-Fuller and the Philips - Perron tests are econometric techniques used to test for the order of integration of market structure and Islamic banking performance. To resolve the problem of causal direction between variables we used Granger causality test. Engle-Granger two-step way is utilized to test for co-integration in the long run equilibrium between market structure and Islamic banking performance. The error correction model is employed to model the relationships between market structure and Islamic banking performance in the long term and short term relationship.

\subsection{Data Analysis Technique}

Various tests have been created and applied to time series data in order to test for the presence of a unit root. This segment examines the normally utilized test for stationery such as the augmented Dicky-Fuller test and the Philips-Perron measurements. Likewise, the Engle-Granger co-integration test has been presented and sequentially utilized to model the market structure and performance for further examination. This study discusses the econometric model and the error correction model that is utilized in the study.

\section{Unit Root Test}

Unit root test can be considered as a stationary test since it is a test to observe whether a particular coefficient of an autoregressive model has a value of one or not (Widarjono, 2016). If the data that has been observed in the unit root test is not stationary, then the next step is to test the integration level. This test is done to find out in the integration of how the data level is stationary. This integration test is similar to a unit root test. Fixed procedures for determining whether the data has become stationary or not, can be seen by comparing the values obtained from the PP statistical regression coefficients with the critical values of the statistical distribution. Before conducting any test to distinguish the presence of a long-run relationship among the variables, the time series data have to be confirmed for stationary. A series is said to be stationary if the mean and variance of the series are independent of any predefined time. It is essential to check on the lasting status of the data before estimating an econometric model in order to avoid spurious regression. This is on the grounds that the utilization of non-stationary data will naturally result in crucial linkage among independent variables, even though theoretically, no such relationships exist. To check on the stationary of the time series, the unit root test has been utilized.

\section{Causality Granger Test}

Granger Causality Test is a test of the two-way relationship between the independent variables and the dependent variable in a regression model (Widarjono, 2016). Regression models usually focus on the one way relationship is and how independent variables influence on the dependent variable. On the other hand, the behavior of economic variables not only maintains a one-way relationship but also shows a two-way relationship, known as causality. Thus the Granger Causality Test is a test in econometrics used to determine whether two variables have a two-way relationship (causality) or not.

\section{Co-integration Test}

Co-integration test between variables is aimed to show the relationship or long-term balance between the independent variables with the dependent variable (Widarjono, 2016). However, in the short run, there is a possibility that an imbalance occurs among these variables. This imbalance is what we often encounter in economic behavior, due to the inability of economic actors to immediately adjust the changes that occur to the behavior of economic variables. Because of this imbalance, the Error Correction Model 
(ECM) is used. ECM exploits the rest/errors of long-term relationships to balance short-term relationships.

$$
R O A=\mathrm{a} 0+\alpha 1 C R+\alpha 2 H H I+\alpha 3 M S F+\alpha 4 M S D+\alpha 5 C A R+\alpha 6 N P F+\alpha 7 O E R+\alpha 8 J K P S+\varepsilon
$$

where ROA is Return on Asset as the Islamic banking performance indicator, CR is Concentration Ratio, HHI is Herfindahl - Hiershman Index, MSF is Market Share of Financing, MSD represents Market Share of Deposit, CAR denotes Capital Adequacy Ratio, NPF is Non Performing Financing, OER is Operating Efficiency Ratio, and BO is Branch Office. After doing the regression equation, we know the residual value. Then we perform the unit test on each remaining root, to determine the stationary level. If the result becomes stationary, it can be said that the data group is co-integrated or in other words, there is a relationship in the long run. Co-integration tests used in this study is the co-integration test developed by Johansen. Johansen test uses statistical trace analysis and critical value for the significant level $\alpha=5 \%$. The null hypothesis if the value of the trace statistic is greater than the critical value at the confidence level $\alpha=5 \%$ or probability value (p-value) is less than $\alpha=5 \%$, indicated co-integration.

\section{Discussion and Empirical Results}

In this study, the ADF and PP tests are utilized to examine the stationary behavior of the market structure and Islamic banking performance models. The empirical results of the ADF and PP tests on each variable in levels and first differences are presented in Table 1.

Table 1

Philips - Peron Result for Unit Roots Test

\begin{tabular}{ccccc}
\hline \multirow{2}{*}{ Variable } & \multicolumn{2}{c}{ Unit Root Test } & PPt-statistics \\
& ADF & $\begin{array}{c}\text { Level } \\
\text { Prob. }\end{array}$ & ADF & $\begin{array}{c}\text { Difference } \\
\text { Prob. }\end{array}$ \\
\hline ROA & -1.866324 & 0.3444 & -8.153352 & 0.0000 \\
MSF & -2.132692 & 0.2334 & -6.204932 & 0.0000 \\
MSD & -0.922261 & 0.7711 & -6.741150 & 0.0000 \\
HHI & -1.195773 & 0.6670 & -8.781362 & 0.0000 \\
CR & -1.381377 & 0.5820 & -7.723929 & 0.0000 \\
\hline
\end{tabular}

Table 1 shows that all the variables are not stationary at the current level when the level of significance is 5\%. The standard ADF and PP unit root test were applied to check the order of integration of these variables (Abidin et al., 2015). Because there are variables that are not stationary, it is necessary to proceed with the unit root test on the level of the first integration degree (First Difference) which is the value of the variable statistics PP is higher than the critical value and it means that this data has been stationary with $p<0.05$ on the degree of integration and can proceed to the next of co-integration test.

In principle, for the Error Correction Model, there is a continuity in the long term that remains between economic variables. If in the short term there is a discontinuity in one period, then the Error Correction Model will correct it in the next period (de-Graft Acquah \& De-Graft Acquah, 2015). This error correction mechanism can be interpreted as aligning the behavior of short term and long term. With this mechanism, spurious regression problems can be avoided through the use of a fixed differentiation variable in the model, but without eliminating the long term information resulting from the use of data differentiation alone. Thus, it can be said that the Error Correction Model is consistent with the concept of co-integration or known as Granger Representation Theorem. Alternative co-integration tests are now used is the cointegration test developed by Johansen. Co-integration test developed by Johansen can be used to determine the number of variables which can be seen in this table below. 
Table 2

Result of Co-integration Johansen Test

\begin{tabular}{ccccc}
\hline Hypothesised & \multicolumn{4}{c}{ Trace 0.05} \\
\hline No. of CE(s) & Eigenvalue & Statistic & Critical Value & Prob.** \\
None $^{*}$ & 0.912754 & 269.4703 & 197.3709 & 0.0000 \\
\hline
\end{tabular}

Table 2 shows that the value of Eigenvalue is 0.912754 with absolute Trace Statistic for 269.4703 higher than the critical value at the rate of $5 \%$ (197.3709), Thus it can be concluded that market structure is mutually co-integrated at a significance level of $5 \%$ on the performance of Islamic banking in Indonesia which measured by Return on Assets (ROA). Granger Causality Test is a test in econometrics used to determine whether two variables have a two-way relationship (causality) or not. Granger Causality Test Results can be seen in Table 3 .

Table 3

Result of the Granger Causality Test

\begin{tabular}{lccc}
\hline Null Hypothesis: & Obs & F-Statistic & Prob. \\
\hline D(CAR) does not Granger Cause D(ROA) & 38 & 2.69192 & 0.0632 \\
D(ROA) does not Granger Cause D(CAR) & & 1.61812 & 0.2052 \\
\hline D(NPF) does not Granger Cause D(ROA) & 38 & 0.54926 & 0.6524 \\
D(ROA) does not Granger Cause D(NPF) & & 1.70592 & 0.1862 \\
\hline D(OER) does not Granger Cause D(ROA) & 38 & 1.35669 & 0.2742 \\
D(ROA) does not Granger Cause D(OER) & & 2.16049 & 0.1127 \\
\hline D(JKPS) does not Granger Cause D(ROA) & 38 & 0.09011 & 0.9649 \\
D(ROA) does not Granger Cause D(JKPS) & & 1.55423 & 0.2203 \\
\hline D(MSF) does not Granger Cause D(ROA) & 38 & 0.32847 & 0.8048 \\
D(ROA) does not Granger Cause D(MSF) & 38 & 1.52233 & 0.2282 \\
\hline D(MSD) does not Granger Cause D(ROA) & & 0.43472 & 0.7297 \\
D(ROA) does not Granger Cause D(MSD) & 38 & 0.92890 & 0.4384 \\
\hline D(HHI) does not Granger Cause D(ROA) & & 2.07401 & 0.7100 \\
D(ROA) does not Granger Cause D(HHI) & 38 & 0.28533 & 0.1239 \\
\hline D(CR) does not Granger Cause D(ROA) & & 2.93596 & 0.0487 \\
D(ROA) does not Granger Cause D(CR) & & &
\end{tabular}

The results show that there are variables that have a unidirectional causality of relationship. It can be seen from the significance of each variable, and there was in the top of $5 \%(p>0.05)$. The existence of co-integration among all variables show a relationship or long-term balance between the variables tested. The result of data processing is accomplished by using a computer program Econometric E-Views version 10.0 with dynamic models ECM can be shown in Table 4.

Unknown Error Correction Term coefficient $(E C T)$ on the model significantly $=0.0001<0.05$. ECT value can be interpreted that the process of adjusting to imbalances the performance of Islamic banking in Indonesia's period relatively quickly, with little value indicated by the ECT. ECT value of -0.559909 means that if there is a balance in the past amounted to $100 \%$, the performance of Islamic banking in Indonesia will adjust to a decrease of $55.99 \%$. Thus it can be interpreted that the process of adjusting the performance of Islamic banking in Indonesia takes 1.78 months (100: 55.99) to achieve balance in full $(100 \%)$ change in the level of performance of Islamic banking in Indonesia. The result of the Coefficient determination in the short term relationship is 0.8728 or $87.28 \%$. In the short term relationship, all structural variables are rejected. This condition happened because in the short term relationship the market structure variable did not impact directly toward Islamic banking performance in Indonesia. The market structure in Indonesia is mastered by several Islamic banking which has the biggest market share from asset, financing and third party fund (Islamic Banking Statistic, 2018). These Islamic banks are Bank 
Syariah Mandiri, Bank BNI Syariah, Bank Muamalat Indonesia, and Bank BRISyariah. However, although this bank masters the big four of Islamic banking in Indonesia, the other Islamic banking in Indonesia still get the good performance because each Islamic bank has the scope of financing and target of the funding based on their market segmentation (Amirudin \& Rahman, 2010).

Table 4

Result of Error Correction Model

\begin{tabular}{rrrrr}
\hline Variable & Coefficient & Std. Error & t-Statistic & Prob. \\
\hline C & -0.013594 & 0.013305 & -1.021764 & 0.3148 \\
D(CAR) & 0.041526 & 0.027767 & 1.495520 & 0.1449 \\
D(NPF) & 0.092814 & 0.058837 & 1.577468 & 0.1248 \\
D(OER) & -0.125387 & 0.009391 & -13.35138 & 0.0000 \\
D(JKPS) & -0.000713 & 0.000275 & -2.596085 & 0.0143 \\
D(MSF) & 0.069115 & 0.539774 & 0.128044 & 0.8989 \\
D(MSD) & 0.002219 & 0.244446 & 0.009077 & 0.9928 \\
D(HHI) & 12.25771 & 7.572062 & 1.618807 & 0.1156 \\
D(CR) & -6.254622 & 4.096843 & -1.526693 & 0.1370 \\
ECT(-1) & $\mathbf{- 0 . 5 5 9 9 0 9}$ & $\mathbf{0 . 1 2 8 7 8 4}$ & $\mathbf{- 4 . 3 4 7 6 6 6}$ & $\mathbf{0 . 0 0 0 1}$ \\
\hline R-squared & 0.901454 & Mean dependent var & 0.019268 \\
Adjusted R-squared & 0.872843 & S.D. dependent var & 0.214341 \\
S.E. of regression & 0.076432 & Akaike info criterion & -2.096615 \\
Sum squared resid & 0.181097 & Schwarz criterion & -1.678670 \\
Log-likelihood & 52.98060 & Hannan-Quinn criter. & -1.944422 \\
F-statistic & 31.50805 & Durbin-Watson stat & 2.825671 \\
Prob(F-statistic) & 0.000000 & & &
\end{tabular}

The long-term estimates carried out in this section are based on the basic theory and previous research namely the performance of Islamic Banking influenced by the variables of market structure which consist market share of financing, market share of the deposit, Herfindahl-Hiershman Index, and concentration ratio. Equations are expressed in long-term relationships or equilibrium relationships as follows:

$$
R O A=a 0+\alpha 1 C R+\alpha 2 H H I+\alpha 3 M S F+\alpha 4 M S D+\alpha 5 C A R+\alpha 6 N P F+\alpha 7 O E R+\alpha 8 J K P S+\varepsilon
$$

The integration between the variables of the market share of financing, market share of the deposit, Herfindahl-Hirschman Index, and concentration ratio through the Islamic banking performance in Indonesia shows there is a long-term balance relationship between variables. The result of a long-term relationship is shown in Table 6.

\section{Table 6}

Result of Long Term Relationship between Variables

Dependent Variable: ROA Date: 12/13/18 Time: 16:17 $\quad$ Included observations: 42 Method: Least Squares $\quad$ Sample: 2015M04 2018M09

\begin{tabular}{|c|c|c|c|c|}
\hline Variable & Coefficient & Std. Error & t-Statistic & Prob. \\
\hline $\mathrm{C}$ & 19.34512 & 3.480026 & 5.558902 & 0.0000 \\
\hline CAR & 0.015279 & 0.021918 & 0.697094 & 0.4906 \\
\hline NPF & 0.011854 & 0.069563 & 0.170409 & 0.8657 \\
\hline OER & -0.128050 & 0.009843 & -13.00906 & 0.0000 \\
\hline MSF & 0.277886 & 0.628264 & 0.442307 & 0.6612 \\
\hline MSD & -0.415416 & 0.152211 & -2.729217 & 0.0101 \\
\hline HHI & 29.39099 & 8.924361 & 3.293344 & 0.0024 \\
\hline CR & -13.13078 & 4.388904 & -2.991812 & 0.0052 \\
\hline JKPS & -0.000684 & 0.000218 & -3.132767 & 0.0036 \\
\hline R-squared & 0.947299 & Mean dependent var & & 0.821429 \\
\hline Adjusted R-squared & 0.934523 & S.D. dependent var & & 0.320461 \\
\hline S.E. of regression & 0.082001 & Akaike info criterion & & -1.976762 \\
\hline Sum squared resid & 0.221897 & Schwarz criterion & & -1.604404 \\
\hline Log-likelihood & 50.51200 & Hannan-Quinn criter. & & -1.840278 \\
\hline F-statistic & 74.14713 & Durbin-Watson stat & & 1.818196 \\
\hline Prob(F-statistic) & 0.000000 & & & \\
\hline
\end{tabular}


The results show the long term relationship between variables market structure and Islamic banking performance in Indonesia. Johansen co-integration test result indicates the presence of co-integration which means that there was a relationship or long term balance between variables. Long term analysis model in this study can be obtained OLS regression function as follows:

$$
\begin{gathered}
R O A=19.34512+0.0152 C A R+0.0118 N P F-0.1280 O E R-0.0006 J K P S+0.2778 M S F \\
-0.4154 M S D+29.39 H H I-13.13 C R
\end{gathered}
$$

The result of the Coefficient determination in the long term relationship is 0.9345 or $93.45 \%$. The result of hypothesis testing for the long term relationship of a market structure variable and Islamic banking performance in Indonesia can be seen in Table 7.

Table 7

Result of Hypothesis Testing for Long Term Relationship

\begin{tabular}{lcccc}
\hline \multicolumn{1}{c}{ Hypothesis } & t-Table & t-Statistic & Sig. 0.05 & Finding \\
\hline $\begin{array}{l}\text { Concentration ratio has a significant effect on Is- } \\
\text { lamic banking performance in Indonesia in the }\end{array}$ & 1.69092 & $|-2.9918|$ & 0.0052 & Accepted \\
long term relationship & & & & \\
$\begin{array}{l}\text { Herfindahl-Hirschman Index has a significant ef- } \\
\text { fect on Islamic banking performance in Indonesia }\end{array}$ & 1.69092 & 3.2933 & 0.0024 & Accepted \\
in the long term relationship & & & & \\
$\begin{array}{l}\text { Market Share of Financing has a significant effect } \\
\text { on Islamic banking performance in Indonesia in } \\
\text { the long term relationship }\end{array}$ & 1.69092 & 0.4423 & 0.6612 & Rejected \\
$\begin{array}{l}\text { Market Share of Deposit has a significant effect } \\
\text { on Islamic banking performance in Indonesia in } \\
\text { the long term relationship }\end{array}$ & 1.69092 & $|-2.7292|$ & 0.0101 & Accepted \\
\hline
\end{tabular}

Based on the hypothesis testing above, in the long term relationship, all the market structure variables except the market share of financing have a significant effect on the performance of Islamic banking in Indonesia. Market share of financing in the long and short term relationship have positive and insignificant influence on the Islamic banking performance in Indonesia measured by the value of return on asset (ROA) and the results are consistent with other findings in the literature (Bhatti \& Hussain, 2010; Asçioglu et al., 2017; Oloniluyi \& Ogunleye, 2016; Bello \& Isola, 2014; Ayadi \& Ellouze, 2013; Yadaruddin, 2012; Arize et al., 2010). This means that if the market share of financing increases, the Islamic banking performance in Indonesia will increase, and vice versa if the market share of financing decreases, the Islamic banking performance will decrease. Market share of Deposit in the long term relationship has a significant and negative effect on the Islamic banking performance in Indonesia (Bhatti \& Hussain, 2010), but in the short term market share of deposit has significant and positive effect on the Islamic banking performance in Indonesia (Oloniluyi \& Ogunleye, 2016; Asçioglu et al., 2017; Bello \& Isola, 2014; Ayadi \& Ellouze, 2013; Yadaruddin, 2012; Arize et al., 2010). This means that if the market share of deposit increased, in the long term the Islamic banking performance will decrease but in the short term the Islamic banking performance will increase. Conversely, when the market share of the deposit decreases, in the long term Islamic banking performance will increase, and in the short term, the Islamic banking performance will decrease.

Herfindahl-Hirschman Index (HHI) in the long term relationship has positive and significant effect through the return on asset as the indicator of Islamic banking performance in Indonesia (Ayadi \& Ellouze, 2013; Yadarudin, 2012; Bello \& Isola, 2014; Hakimi et al., 2015). However, in the short term relationship, HHI has a positive and insignificant effect through the return on asset. This shows that if the Herfindahl - Hiershman Index increases, in the long term and short term relationship the Islamic 
banking performance will increase, while the Herfindahl - Hiershman Index decreases, the Islamic banking performance will decrease. Concentration Ratio (CR) in the long term relationship has negative and significant effect on ROA in Islamic banking in Indonesia, which is consistent with the results of other studies (Bade \& Parkin, 2007; Oloniluyi \& Ogunleye, 2016; Hakimi et al., 2015; Yadarudin, 2015; Ahamed, 2012; Naylah, 2010; Bhatti, 2010). Concentration Ratio (CR) in the long term relationship has negative and significant effect on ROA in Islamic banking in Indonesia, which is consistent with the results of other studies (Bade \& Parkin, 2007; Oloniluyi \& Ogunleye, 2016; Hakimi et al., 2015; Yadarudin, 2015; Ahamed, 2012; Naylah, 2010; Bhatti, 2010). However, in the short term relationship, concentration ratio has a negative and insignificant effect through the return on an asset as the Islamic banking performance (Katib, 2004; Arize et al., 2010). This means that if the concentration ratio increases, the Islamic banking performance in the long term and short term relationship will decrease and vice versa if the concentration ratio is decreased then the Islamic banking performance in Indonesia will increase.

\section{Conclusion}

This study has attempted to study the relationship between market structure and Islamic banking performance in Indonesia in the short and long term. Using co-integration techniques, the study has investigated the long term relationship between market structure and Islamic banking performance in Indonesia in the structure conduct performance approach. The result indicates that the market structure variables were stationary at first difference. Granger causality test has also shown unidirectional causality in the twoway relationship between the independent and dependent variables in a regression model. The result of the error correction model has shown that none of the market structure variables in the short term relationship had any significant effect on Islamic banking performance growth. From the government perspective, since the Indonesia government aimed to improve the economy of the banking industry particularly Islamic banking industry, this study helps Indonesia's development plans in increasing the Islamic banking performance and the management commitment to improve the Islamic banking performance growth.

\section{References}

Abidin, I. S. Z., Haseeb, M., Azam, M., \& Islam, R. (2015). Foreign direct investment, financial Development, international trade and energy consumption: Panel data evidence from selected ASEAN Countries. International Journal of Energy Economics and Policy, 5(3), 841-850.

Abidin, I. S. Z., Haseeb, M. (2018). Malaysia-GCC Bilateral Trade, Macroeconomic Indicators and Islamic Finance Linkages: A Gravity Model Approach. Academy of Accounting and Financial Studies Journal. 22, 178, 1528-2635.

Ahamed, M. M. (2012). Market structure and performance of Bangladesh banking industry: A panel data analysis. The Bangladesh Development Studies, 35(3), 1-18.

Amirudin, H. W., \& Rahman, L.O.A. (2010). Studi Preferensi dan Segmentasi Pasar BRISyariah, Kasus Masyarakat Kota Bogor (Studying of BRISharia Preferences and market segmentation, Case Bogor Society). Thesis. Statistika Terapan. Institut Pertanian Bogor.

Arize, A. C., Kallianotis, I. N., Kasibhatla, K. M., Malindretos, J., \& Rivera-Solis, L. E. (2008). Empirical evidence on the relationships between concentration and profitability in Latin American banking, MPRA Paper No. 34902 87-96.

Asçioglu, A., Holowczak, R., Louton, D., \& Saraoglu, H. (2017). The evolution of market share among the US options market platforms. The Quarterly Review of Economics and Finance, 64, 196-214.

Ayadi, I., \& Ellouze, A. (2013). Market structure and performance of Tunisian banks. International Journal of Economics and Financial Issues, 3(2), 345-354.

Bade, R., \& Parkin, M. (2009). Essential foundations of economics. Pearson Education.

Basheer, M. F., KhorramI, A. A. A., \& Hassan, S. G. (2018). Patronage factors of Islamic banking system in Pakistan. Academy of Accounting and Financial Studies Journal, 22(1). 
Basheer, M. F., Waemustafa, W., \& Ahmad, A. A. (2018). The Paradox of Managerial Ownership and Financial Decisions of the Textile Sector: An Asian Market Perspective. The Journal of Social Sciences Research, 4, 184-190.

Bello, M., \& Isola, W. A. (2014). Empirical analysis of structure-conduct-performance paradigm on Nigerian banking industry. The Empirical Econometrics and Quantitative Economics Letters, 3(3), 2434.

Belkhaoui, S., Lakhal, L., Lakhal, F., \& Hellara, S. (2014). Market structure, strategic choices and bank performance: a path model. Managerial Finance, 40(6), 538-564.

Bhatti, G. A., \& Hussain, H. (2010). Evidence on structure conduct performance hypothesis in Pakistani commercial banks. International Journal of Business and Management, 5(9), 174.

Hakimi, A., Hamdi, H., \& Djlassi, M. (2013). Testing the concentration-performance relationship in the Tunisian banking sector. Journal of Economics and Business18(2).

Haseeb, M. (2018). Emerging issues in islamic banking \& finance: Challenges and Solutions. Academy of Accounting and Financial Studies Journal, 22, 1-5.

Katib, M. N. (2004, December). Market structure and performance in the Malaysian banking industry: a robust estimation. In 8th Capital Markets Conference, Indian Institute of Capital Markets Paper.

Beck, T., Demirgüç-Kunt, A., \& Levine, R. (2003). Bank supervision and corporate finance. The World Bank.

Beck, T., Demirgüç-Kunt, A., \& Levine, R. (2006). Bank concentration, competition, and crises: First results. Journal of Banking \& Finance, 30(5), 1581-1603.

Douglas, F. Greer. 1992. Industrial Organizattion and Public Policy. New York: Macmillan.

de-Graft Acquah, H., \& De-Graft Acquah, J. (2015). An application of the error correction model in analyzing the long run equilibrium between Ghana's exports and imports. APSTRACT: Applied Studies in Agribusiness and Commerce, 9(3), 57-62.

Naylah, M. (2010). Pengaruh Struktur Pasar Terhadap Kinerja Industri Perbankan Indonesia. Thesis. Magister Ilmu Ekonomi dan Studi Pembangunan. Universitas Diponegoro.

Nizar, S.M.R. (2015). Consumer attitudes and purchase intentions toward Islamic banks: The influence of religiosity. International Journal of Bank Marketing, 33(2).

Nurwati, E., Achsani, N. A., Hafidhuddin, D., \& Nuryartono, N. (2014). Market Structure and Bank Performance: Empirical Evidence of Islamic Banking in Indonesia. Asian Social Science, 10(10), 105.

Oloniluyi, A.E., \& Ogunleye, E. O. (2016). The relevance of Structure, Conduct and Performance Paradigm in the Nigerian Banking Industry. Journal of Economics and Sustainable Development. 7(19).

Otoritas Jasa Keuangan. (2017). Islamic Banking Statistic. Available Online At Http://www.Ojk.go.id.

Otoritas Jasa Keuangan. (2017). Statistik Perbankan Syariah. Available Online At Http://www.Ojk.go.id.

Otoritas Jasa Keuangan. (2018). Statistik Perbankan Indonesia. May 2018. Available Online At Http://www.Ojk.go.id.

Otoritas Jasa Keuangan. (2018). Statistik Perbankan Syariah. February 2018. Available Online At Http://www.Ojk.go.id.

TA, T. S., O'Neill, C., \& Rowan, N. J. (2013). The Use of Cointegration and Error Correction Modelling To Investigate the Influence of Diabetes and Associated Medical Services Expenditure on Economic Growth in Malaysia. Journal of Asian Scientific Research, 3(6), 644.

Rahman, N., Othman, M., Yajid, M., Rahman, S., Yaakob, A., Masri, R., ... \& Ibrahim, Z. (2018). Impact of strategic leadership on organizational performance, strategic orientation and operational strategy. Management Science Letters, 8(12), 1387-1398.

Singh, S. K., Singh, S., \& Raghav, S. (2014). Does Market Structure Matter? Evidence from the Indian Cement Industry. Studies in Business and Economics, 9(3).

Schuster, L. (1984). Profitability and Market Share of Banks. Journal Of Bank Research, Spring, 56-61.

Widarjono, A. (2016). Ekonometrika Teori dan Aplikasinya. First Edition. Yogyakarta: Ekonisia.

Yadaruddin, R. (2015). Dampak Struktur Pasar dan Efisiensi terhadap Kinerja Bank Pembangunan Daerah. Jurnal Kinerja, 19(2). 139-148. 
(C) 2019 by the authors; licensee Growing Science, Canada. This is an open access article distributed under the terms and conditions of the Creative Commons Attribution (CCBY) license (http://creativecommons.org/licenses/by/4.0/). 